\title{
New Technique to Create a Suspension Containing Bacteriophages and How It Can Be Used to Control Cabbage Leaf Spot Caused by Xanthomonas campestris PV. campestris
}

\author{
Igor Villela Marroni, José Carlos Germani \\ Department of Basic Health Sciences, Rua Sarmento Leite, Universidade Federal do Rio Grande do Sul, Porto \\ Alegre, Brazil \\ Email: imarroni@terra.com.br
}

Received 25 January 2014; revised 26 February 2014; accepted 4 March 2014

Copyright (C) 2014 by authors and Scientific Research Publishing Inc.

This work is licensed under the Creative Commons Attribution International License (CC BY).

http://creativecommons.org/licenses/by/4.0/

(c) (1) Open Access

\begin{abstract}
The purpose of the present study was to develop a new method for producing and identifying a bacteriophage suspension and research its potential against plant bacteria. The suspension obtained with the new technique was effective in controlling Xanthomonas campestris PV. campestris both in vitro and in vivo. A difference was observed between the suspension with pathogen (PLP) and crude suspension with lesioned plant without the pathogen originated from it (PLN). Clear zones were observed at $48 \mathrm{~h} / 28^{\circ} \mathrm{C}$ in both (PLS) suspension added saccharose and (PLP). Although PLP and PLS treatments showed no statistical difference in CFU values $\left(5 \times 10^{5}\right.$ and $1 \times 10^{5}$, respectively), they differed from the crude suspension (PLN) and the control. Then, in vivo assessment of suspensions with clear zones in the dishes was performed. In vivo (PLPS) and (PLPP) treatments consisting of inoculum were added to the crude suspensions (PLS and PLP) to increase bacteriophages. A decrease in the disease severity index compared to the control was observed, showing that treatment with the phage suspension protects the plant. The lowest disease indexes were reported with (PLP) and (PLS), with values of 1.46 and 1.40, respectively. The highest averages in dry matter (5.1 in both treatments) were obtained with (PLP) and (PLS) treatments.
\end{abstract}

\section{Keywords}

Biocontrol; Virus; Bacteria; Disease Index

\section{Introduction}

Few viruses with parasitic DNA are capable of causing damage to their host. Bacteriophages are an exception,

How to cite this paper: Marroni, I.V. and Germani, J.C. (2014) New Technique to Create a Suspension Containing Bacteriophages and How It Can Be Used to Control Cabbage Leaf Spot Caused by Xanthomonas campestris PV. campestris. Agricultural Sciences, 5, 286-297. http://dx.doi.org/10.4236/as.2014.54031 
since they are usually constituted of a DNA strand and they parasitize bacteria. Bacteriophages, also known as phages, are viruses with different characteristics from other viruses, as they do not enter the cell with their capsid. When inserting their genetic material into the bacteria, they initiate the synthesis of other phages in a process known as lysin. Phages only infect bacteria or archaebacteria, and they all feature genomes formed of DNA [1], whose form protects them during handling because the DNA is composed of hydrogen bonds, which make them more stable to adverse conditions. Thus, phages are more stable than most viruses that occur naturally. The study of phages is not new, and early research has produced a lot of information. The activity of phages was discovered by d'Herelle in 1915 [2], who reported on the filtrate and agents that the bacterial cell was lysed. Furthermore, these tiny structures spread easily in their host environment. Boyd et al. [3] conducted a study showing that tomato plants absorbed the virus after $3 \mathrm{~h}$ of submerging their roots in a suspension containing phages of Agrobacterium tumefaciens. After two weeks, the phages could still be identified in the plant. Several other studies have questioned their effectiveness in biological control [4]. After that, the question of phages was put on hold for a long period of time, since it was thought that chemicals could take their place in disease plants control [5]. Recent findings, e.g. antibiotic-resistant strains, led to new researches and new forms of control. Concomitantly, there was a need to find methods more in tune with sustainability.

Bacterial diseases in plants constitute a permanent problem for agriculture in general. They cause significant losses to farmers and, consequently, to the global economy, since there are still no effective ways to control them. The ability to control diseases is mainly associated with resistant cultivars; however, environmental factors such as humidity favor virulence [6]. Unlike fungi, bacteria are not effectively controlled by chemical means. One form of commonly used control refers to cupric agents and antibiotics such as streptomycin; however, since they can produce resistance in pathogens, new research focusing on biological control of plant bacterial diseases [7] was conducted. Rhizobacteria are at the forefront of biological control, usually isolated from suppressive soils, such as bacteria of the genus Pseudomonas and Bacillus, which can enhance chemical control, especially to overcome fungal diseases. Stockwell \& Stack [8] observed that the application of Pseudomonas spp. and BlightBan A506 in pear and apple trees suppressed bacterial blight caused by Erwinia amylovora. Maketon et al. [9] used the synergism between Bacillus and Trichoderma to inhibit tobacco diseases, including bacterial wilt (Ralstonia solanacearum), damping-off (Pythium aphanidermatum), and frogeye leaf spot (Cercospora nicotiana). The problem of using bacteria is that they can produce antibiosis, toxins and enzymes, which can cause unpredictable reactions in the local microbiota [10]. Although there are very few studies on the action of virus in biological control of plant bacterial diseases in the world, it is known that they effectively parasitize these microorganisms in nature through the lytic process. Each phage is specific to a particular bacterium, therefore unable to infect other forms of life [11]. Therefore, in principle, the method should be applicable to any bacteria. There have been talks of a method of biological control that does not require high investments for its application or experts in virology, so it can be adapted to developing countries' conditions. Few studies on biological control of plant disease using phages can be found through search engines. Search tools such as Scielo, Phytophatology, Plant Pathology, Biological Control, and Biocontrol produce no references to this potential antagonist. Only Plant Disease lists six studies of viruses used for biological control in plants, most of which were obtained in laboratories. Nagy et al. [12] carried out an extensive review of what is being done in the control of fire blight using of commercial bacteriophages. The ability of the phage controller is already known and is used mainly in the medical field to control antibiotic resistant bacterial strains in hospitals [13] [14]. In the available studies, which apply a single methodology, the authors isolated the pathogen using virology techniques [15].

Several reports assert that phages are not effective in biocontrol based on the poor assessment of the virion-containing suspension. In those studies, a large amount of organic matter capable of inhibiting bacterial growth was present in the virion suspension; thus, it is not known whether the change in bacterial growth was caused by phages or by enzymes and toxins. This methodology is taught in universities in Brazil [16] (Figure 1).

\section{Materials and Methods}

Leaves of cabbage (Brassica oleracea capitata), showing typical lesions of Xanthomonas campestris PV. campestris, were cut in the affected areas, favoring the bacterial exudate of Xanthomonas campestris PV. campestris. Fragments of the leaves were placed in Erlenmeyer flasks containing $150 \mathrm{ml}$ of liquid culture medium GYCA (glucose $-10 \mathrm{~g}$, yeast extract $-5 \mathrm{~g}, \mathrm{CaCO}_{3}-30 \mathrm{~g}$, distilled $\mathrm{H}_{2} \mathrm{O}-1000 \mathrm{ml}$ ) and incubated for $24 \mathrm{~h}$ at $28^{\circ} \mathrm{C}$ in a 


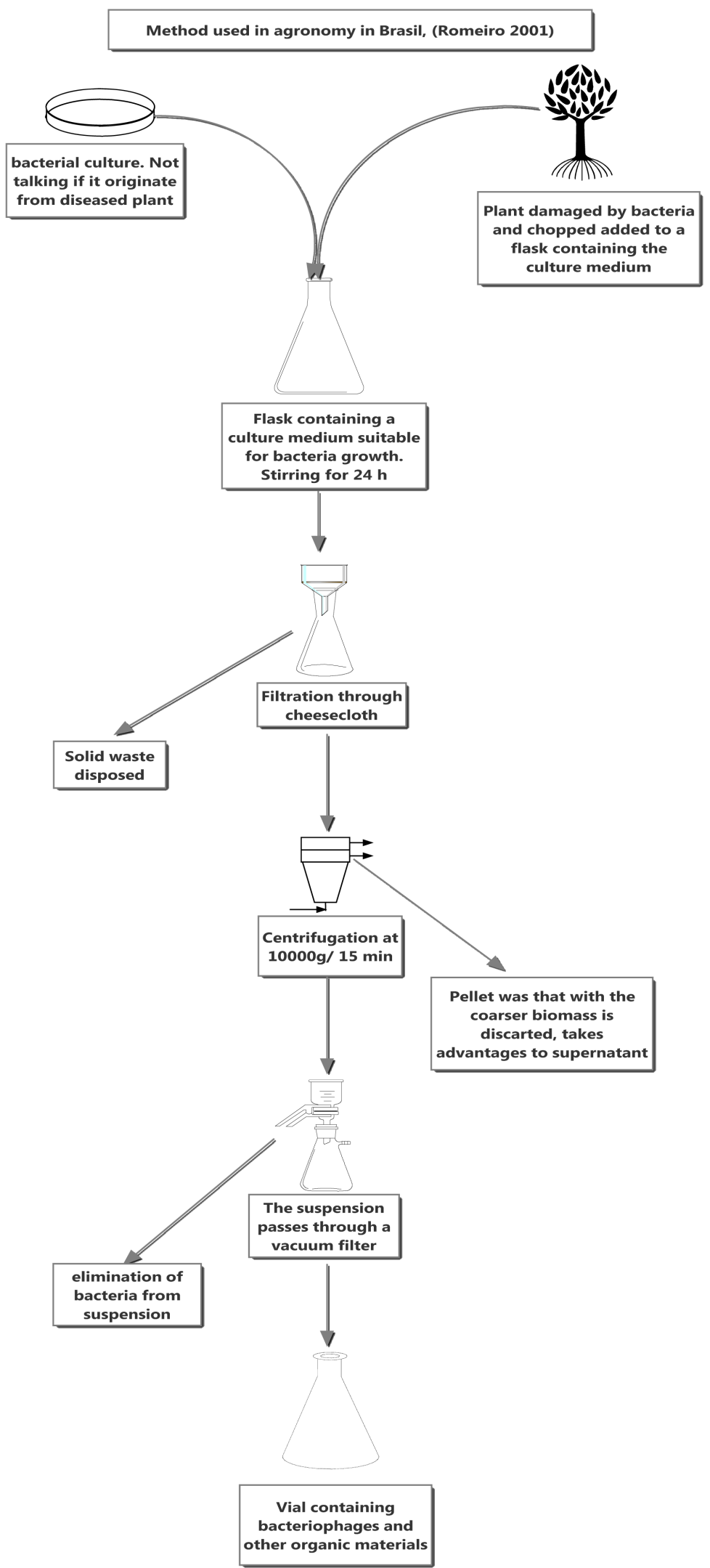

Figure 1. Typical method to isolated phages in Brazil agronomy [16]. 
orbital shaker. Inoculum with bacteria that was previously isolated from the lesion and biochemically identified as Xanthomonas campestris PV. campestris was added to the flasks. A suspension with injured cabbage leaves, in which the pathogen had intentionally not been isolated, was also prepared. In this case, a microorganism isolated from another leaf was inoculated. This methodology is used to verify whether the phages found in the bacteria would be as efficient as in a different niche from that in which they were isolated, in the present case, from leaves probably infected by a different subspecies (PLN) of Xanthomonas campestris PV. campestris. Subsequently, the preparation methods of the phage suspension were compared. After that, a carbohydrate sourcesaccharose (2 g) — was added to form a new suspension (PLS) from the suspension with the isolated and inoculated pathogen (PLP) to produce an exponential increase in bacteria count.

The suspensions used in the study were then classified as follows:

PLP = Crude suspension with lesioned plant and the pathogen isolated from it;

PLN = Crude suspension with lesioned plant without the pathogen originated from it;

PLS = Crude suspension with injured plant and pathogen isolated from it (PLP)

with the addition of $2 \mathrm{~g}$ of saccharose to increase bacteria and phage count;

PLPP = Suspension used for inoculation in plants, PLP modified by adding

bacterial inoculum to increase virion count;

PLPS = Suspension used for plant inoculation, PLS modified by adding bacterial

inoculum to increase virion count in the suspension.

The crude suspension, containing $150 \mathrm{ml}$ of liquid culture medium (GYCA) plus $10 \mathrm{~g}$ of lesioned cabbage leaf, with PLN and PLP pathogen inoculum (in this case, with or without the addition of $2 \mathrm{~g}$ of saccharose) isolated from the plant itself, or not isolated from the plant lesion, was filtered through gauze. Thus, a (free) extract was obtained from the biomass. By centrifuging at $5000 \mathrm{~g}$ for $45 \mathrm{~min}$, we extracted the denser content (Janetzki $\mathrm{k} 23$ ). After that, the supernatant was filtered through a $0.22 \mu \mathrm{m}$ Millipore ${ }^{\circledR}$ filter to remove the bacteria and the filtrates obtained thereof were divided into two parts according to the alternative method proposed by Svensson \& Christianson [17]. One of the aliquots was heated to $95^{\circ} \mathrm{C}$ for $5 \mathrm{~min}$, sufficient time and temperature to avoid denaturing proteins and enzymes that could hinder the assessment; therefore this aliquot contained no virion (virus cell out off host). The second aliquot was not heated, and consequently the virion was present in the suspension, thus confirming with greater certainty that inhibition occurred due to the presence of virions. In parallel tests, the pathogen was related to compounds produced by its host (in this case, the plant without lesion) to confirm that plant compounds do not alter bacterial development. Therefore, healthy cabbage leaves were put into a water bath at $100^{\circ} \mathrm{C}$ for $1 \mathrm{~h}$ and then separated from the suspension, the liquid medium, and were stored at $4^{\circ} \mathrm{C}$ until further use. To promote growth, $100 \mathrm{ml}$ of a suspension containing Xanthomonas campestris PV. campestris, as well as $100 \mathrm{ml}$ of plant fluid, were added to approximately $150 \mathrm{ml}$ of GYCA liquid medium for $24 \mathrm{~h}$ at a temperature of $28^{\circ} \mathrm{C}$. After the estimated time, a sample of the suspension $(100 \mathrm{ml})$ was collected and spread in GYCA culture medium solidified on Petri dishes with the aid of a Drigalsky loop. With the same time and temperature parameters, $100 \mathrm{ml}$ of distilled water and the same amount of inoculum, produced from the pathogen suspension, were added to this culture medium. After growth of the bacteria, a 100- $\mu$ l sample was collected and the fluid was spread on GYCA medium solidified in Petri dishes using a Drigalsky loop. The dishes with plant fluid and sterile water were incubated at $28^{\circ} \mathrm{C}$ for $24 \mathrm{~h}$. The test was considered positive if the bacteria grew equally on both dishes, indicating that the toxins produced by the plant did not inhibit pathogen growth.

After confirming no activity of the plant fluid on the pathogen, we proceeded with the experiment. In GYCA liquid medium (125 ml) the pathogen Xanthomonas campestris PV. campestris was inoculated together with 100 $\mu \mathrm{l}$ of the suspension containing the virion and, at the same time, of the suspension supposedly not containing the virion. After that, in both cases, the bacteria were incubated at $28^{\circ} \mathrm{C}$ for $24 \mathrm{~h}$, observing the delay time required for bacterial growth and the antagonistic action of the viruses. After development or not of the bacteria in the Petri dishes containing GYCA medium, $100 \mu \mathrm{l}$ were spread on the medium with a Drigalsky loop. The Petri dishes were then incubated at a controlled temperature of $28^{\circ} \mathrm{C}$ for $48 \mathrm{~h}$ and bacterial growth - or lack of it - was observed. To proceed with the experiment, the microorganism had to grow in the medium in which the suspension that inactivated the virus by thermal treatment was seeded, and not grow—or show deficiency (e.g. little growth) — where the physical treatment was not used, indicating the potential presence of virus.

The effect of the suspension containing phages on bacterial count was also assessed. To that end, the method of dilution in Petri dish was used for CFU count. The bacteria, clipped into an Erlenmeyer flask in the $150 \mathrm{ml}$ of GYCA liquid medium, were incubated at $28^{\circ} \mathrm{C}$ for $24 \mathrm{~h}$ until their growth. Then, a $100-\mu \mathrm{l}$ aliquot of the suspen- 
sion containing the bacteria was collected for approximately $150 \mathrm{ml}$ of GYCA liquid medium. In the same medium, the different phage suspensions (PLP, PLS and PLN) were inoculated at a concentration of $100 \mu$, and the activity of each suspension in relation to plant bacteria was controlled. The Erlenmeyer flasks were then placed in an orbital shaker at $28^{\circ} \mathrm{C}$ for $24 \mathrm{~h}$. After the growth period, a serial dilution was performed. The same treatment was used with the control; however, instead of the suspension containing phages, $100 \mathrm{ml}$ of sterile water were added to the medium in which the bacteria had grown. After $24 \mathrm{~h}$ incubation at $28^{\circ} \mathrm{C}$ we assessed whether bacterial count had changed when with the virus. Bacterial count would then be a result of tests in triplicate at $10^{-3}$ and $10^{-4}$ dilutions. The methodology used in experiment is explained step by step in Figure 2 .

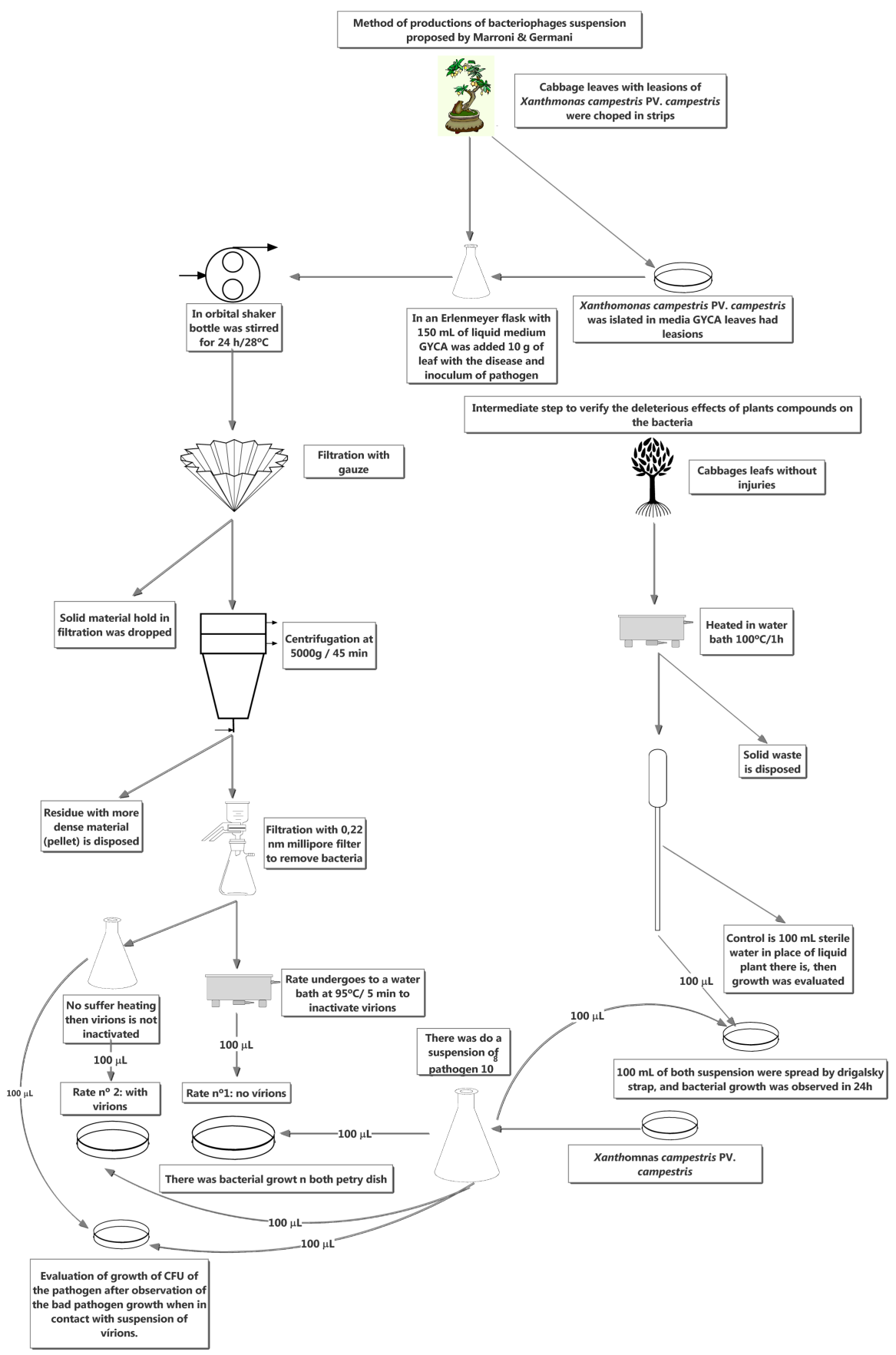

Figure 2. New method proposed by Marroni, and Germani to produce an aqueous suspension containing only bacteriophages. 


\subsection{In Vivo Test}

If the test was positive for phage production in vitro, a test in greenhouse at $10^{\circ} \mathrm{C}-20^{\circ} \mathrm{C}$ was performed with one-month-old cabbage seedlings. A new technique for increasing virion count was tested. Thus, the suspensions that were positive in the PLS and PLP in vitro assessment (producing clear zones in the culture media) were inoculated with the pathogen (host), to induce the lytic process and to increase antagonist count in the suspension, thus producing the PLPP and PLPS suspensions, respectively. A virion suspension, to which sterile water was added instead of the suspension containing bacteria, was used to evaluate whether inoculum addition to the suspension containing phages would induce greater control of plant bacterial diseases. The control consisted merely of inoculating cabbage leaves with the pathogen. This procedure with the control confirmed Koch's postulates and indicated by biochemical assessment that it was actually Xanthomonas campestris PV. campestris. For the in vivo assessment, tests were performed in triplicate: the cabbage seedlings were randomly arranged on the bench, then a suspension of $1 \times 10^{8}$ of pathogen was prepared and $100 \mu 1$ of the suspension containing phages were added; the control received the same treatment, but with the addition of water. With scissors submerged in the suspension, cuts were made in the leaf blade of five leaves per plant, obtaining a total of 15 lesions/treatment, one plant/pot, with the test being performed in triplicate. The seedlings were sealed for $24 \mathrm{~h}$ in polyethylene bags to favor infection by the pathogen. After one month, lesions were observed on the leaves. Then, a diagrammatic scale with three different levels of disease severity was prepared like is showed in Figure 3.

The dry matter of the plants was also analyzed. Forty-five-day-old seedlings were pulled out from their substrate, and the soil attached to the roots was completely removed. They were then placed in polyethylene bags at a controlled temperature of $40^{\circ} \mathrm{C}$ for two weeks. After that, the seedlings were weighed on a semi-analytical scale (Marte).

\subsection{Statistical Analysis}

The analysis of variance (ANOVA) was performed by verifying the difference of the means by Duncan's test at a $5 \%$ level of probability, using Assistat ${ }^{\circledR}$ software.

\section{Results}

The difference between the pathogen in the suspension subjected to thermal treatment that inactivated the mi-

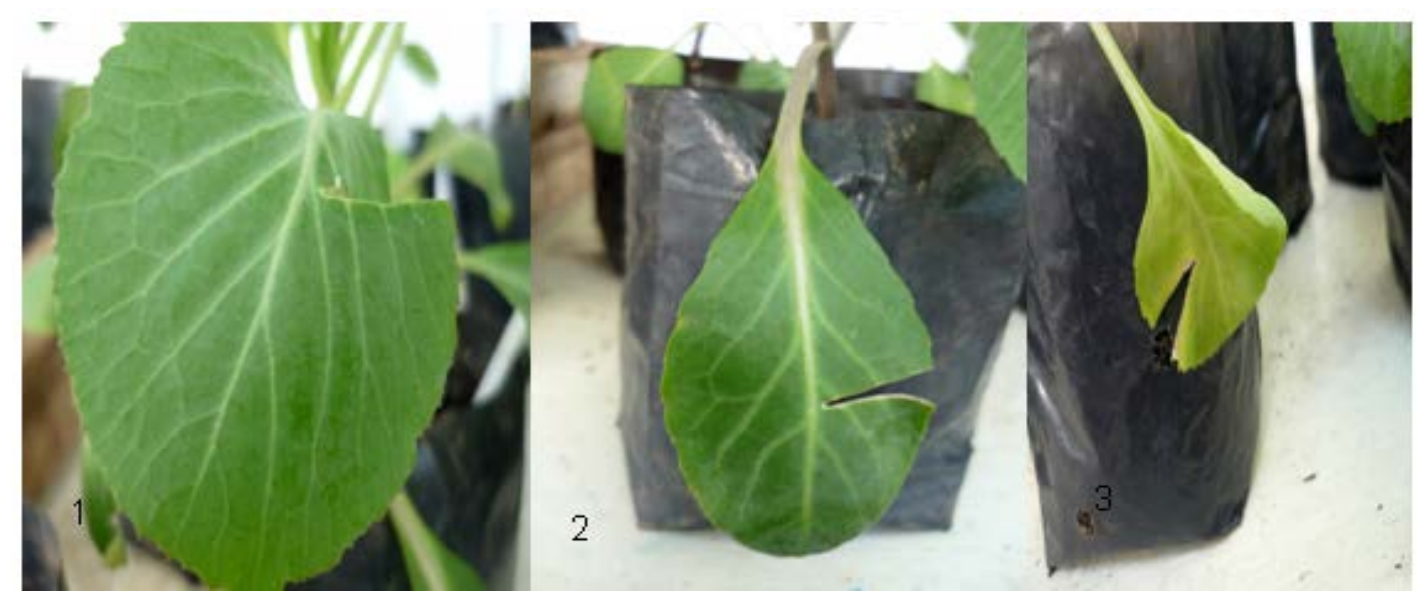

Figure 3. Disease severity scale of cabbage leaves submitted to different treatments: (1) no symptoms, (2) mild symptoms such as necrosis in the cut area, and few small yellow spots, (3) severe symptoms, such as overall leaf chlorosis, important necrosis in the cut area. To prepare an index of plant disease severity, we used the alternative formula proposed by Marroni et al. [18], $\Sigma \mathrm{ni}(1 \sim 3) / 5$, where $\mathrm{n}$ is the number of seedlings and $\mathrm{i}$ is the index of symptom severity shown by the plants as follows: 1 no symptoms; 2 mild symptoms such as necrosis in the cut area and few small yellow spots; 3 severe symptoms of strong necrosis in the cut area and leaf chlorosis, 5 is number of lesions per plant. It is important to note that the higher the index, the higher the disease severity, and that we made one lesion per leaf. 
croorganism (virus), and the suspension supposedly containing virions was significant. 1) Action of the PLS suspension (PLP suspension with $2 \mathrm{~g}$ of sucrose); the picture indicates that the increase in bacterial count, due to the supplementation of an additional source of carbohydrate, is positive to the increase in virion control in relation to the pathogen; 2) shows the reaction of bacteria when exposed to the suspension in which the virion was isolated from the pathogen and that the clear zone is not as great as when saccharose is added to the same suspension; 3) dish showing the fullest growth of the pathogen, since the virus was inactivated; 4) use of pathogen hosting phages other than from the lesion. This is because the phages that are in suspension have more difficulty parasitizing the bacterium suspension with respect to PLP, in which case the phage and host-originated bacteria would have higher affinity, mainly because of the high speciality that this kind of virus has in contrast to the PLN suspension It is worth noting Figure 4(d), in which the pathogen in its culture medium with the virus added to it shows less pigmentation. This is probably due to the action of the virus in the pathogen, indicating the death of bacteria probably by phage activity, but not enough to the point of forming clearing zones. It can even be observed that the lighter form on the dish is not localized, but rather global, indicating a potential infestation of the virus in the bacterial community. Figure 4(c) seems to be more pigmented than the others, probably due to the production of xanthomonadin, a pigment specific to this kind of bacteria, showing that it thrives in the absence of the virus.

Following in manuscript is showed Figure 4 that is about how pathogen reacts in contact with antagonist.

According Table 1 the PLS and PLP treatments showed a higher decrease in bacteria CFUs. This is because phages are very specific to their host. This deficiency is often avoided by their synergistic use with other forms of control [19] [20]. However, Figure 4(d) shows that where the bacteria grew there is a less pigmented area than in dish c, where the virus was inactivated. This is probably an indication that the phages control the pathogen, as evidenced by the decrease in xanthomonadin and the difference in viscosity seen in the figures, although not to the point of forming halos, as in the PLP and PLS treatments (Figures 4(a) and (b)).

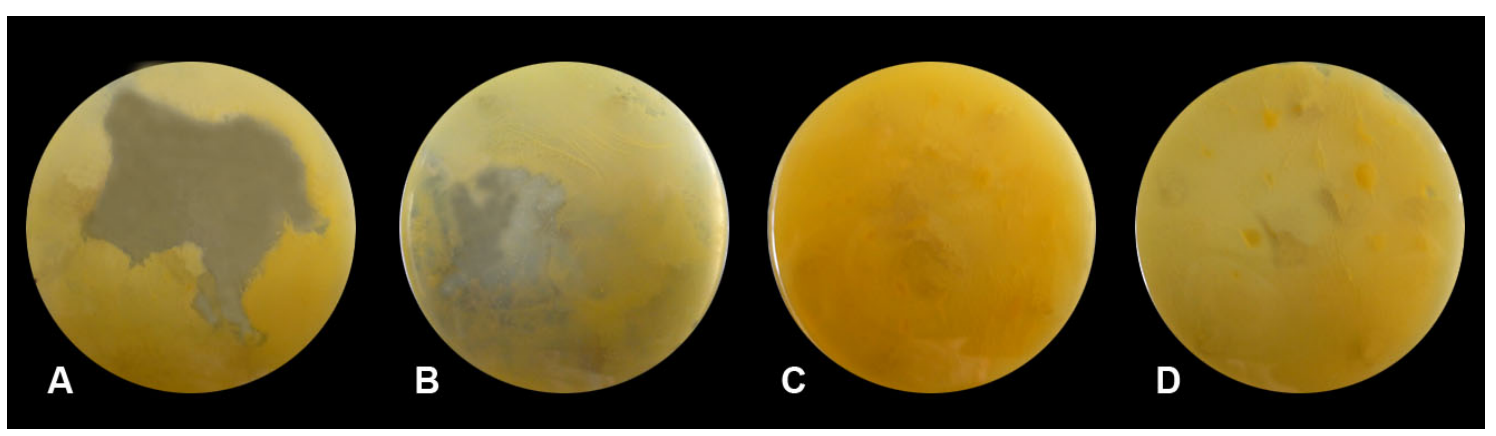

Figure 4. In vitro test after $48 \mathrm{~h}$ with different suspensions containing bacteriophages. (A) PLP suspension by adding $2 \mathrm{~g}$ of saccharose (PLS); (B) PLP suspension of bacteriophages, in which the virus was isolated from the producer of the lesion and its causative agent; (C) Where the virus suspension is inactivated $95^{\circ} \mathrm{C}, 5 \mathrm{~min}$; (D) Effect of suspension not created the pathogen itself (PLN).

Table 1. CFU count: shows that the PLP (crude suspension with lesioned plant and the pathogen isolated from it) and PLS (crude suspension with injured plant and pathogen isolated from it (PLP)) suspensions produced averages of $5 \times 10^{5}$ and $1 \times$ $10^{5}$, respectively, for CFU formation and that both suspensions differed statistically from the PLN (crude suspension with lesioned plant without the pathogen originated from it); treatment and the control. The PLN suspension showed a positive result, differing from the control, and obtained values of $3.2 \times 10^{7}$ and $5 \times 10^{8}$, respectively; however, the PLN suspension was inferior to the other two treatments. Those who have similar letter in the column do not differ statistically among themselves. The treatments of both experiments were different by Duncan test at $5 \%$ probability.

\begin{tabular}{ccc}
\hline Crude suspension & CFUs means & Statistical significance \\
\hline PLP & $5 \times 10^{5}$ & c \\
PLS & $1 \times 10^{5}$ & $\mathrm{c}$ \\
PLN & $3.2 \times 10^{7}$ & $\mathrm{~b}$ \\
Control & $5 \times 10^{8}$ & $\mathrm{a}$ \\
\hline
\end{tabular}


As shown in Table 2 and Figure 5, all PLP, PLS, PLPP and PLPS treatments produce disease index averages of 1.46, 1.66, 1.4 and 1.53, respectively, with no statistical difference. At first glance, it shows that introducing inoculum in the virion-containing suspension was not positive in controlling the plant bacterial disease, as these treatments were statistically equivalent to the original PLP and PLS treatments; however, they were superior to both the control and when water was added to the suspension. However, Table 2 shows us at the same time that there is a difference between the addition of water and the host inoculum, as PLPP differed statistically from the treatment with water (1.66 and 2.13, respectively). Although the PLPS treatment was superior to treatment with water, it did not differ statistically, as shown in Table 2 and Figure 5.

The dry weight did not show significant differences between treatments with water and the control, with averages of 3.4 and 3.3, respectively. These values are not statistically different from the PLPP treatment (4.5). The PLP, PLS and PLPS treatments did not differ statistically from PLPP, but it did from the treatment with water and from the control, with values of 5.1, 5.1 and $4.8 \mathrm{~g}$, respectively. This small difference could be explained by the fact that Xanthomonas is a bacterium of the plant's phylloplane. However, it might be possible that some

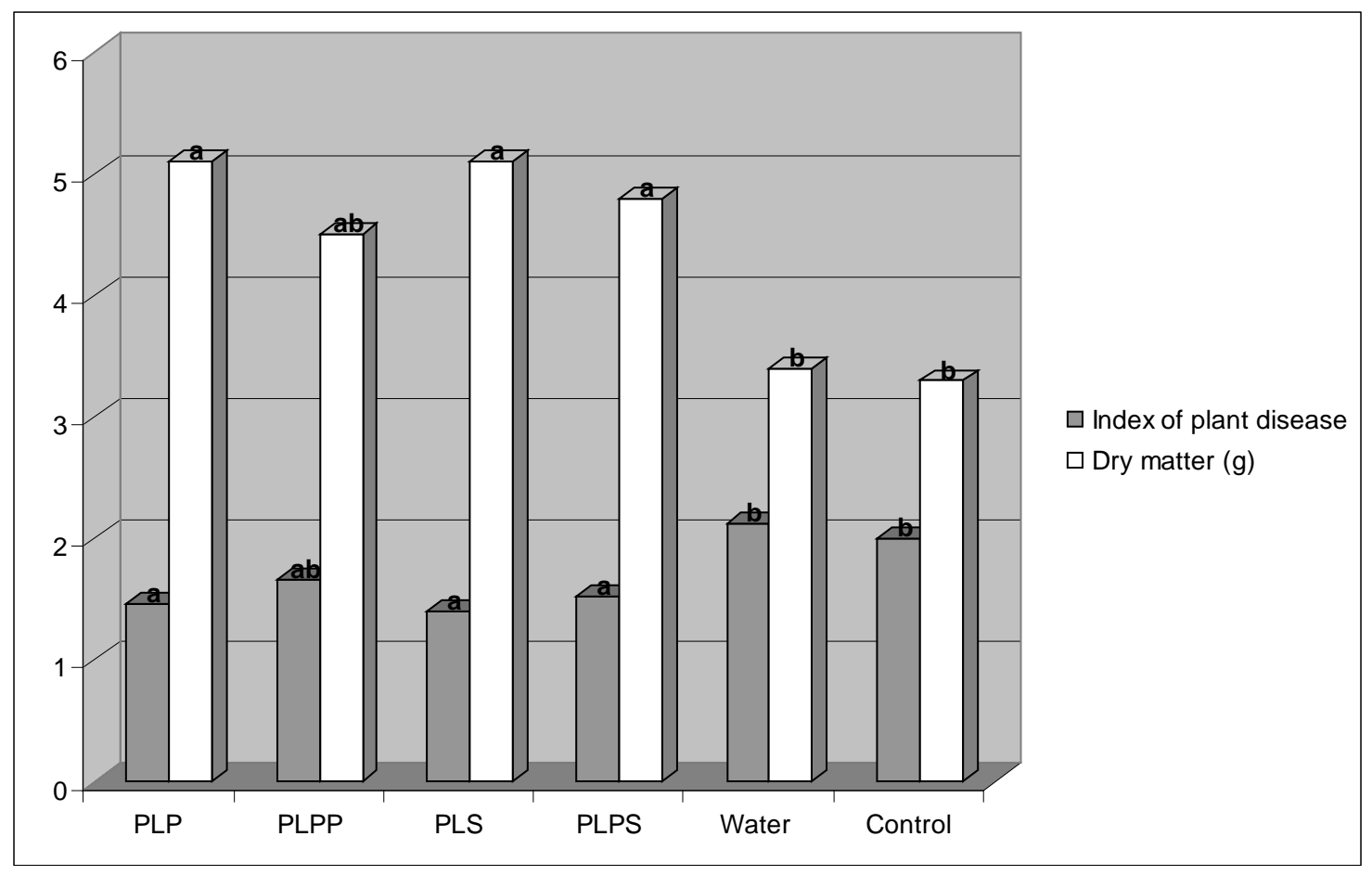

Figure 5. Index of plant disease and dry matter: graphics with same word don’t differ.

Table 2. Index of plant disease and dry matter: 1) to the left of the table to see if the average disease index of different treatments. Those who have similar letter in the column do not differ statistically among themselves for the index of plant disease; 2) on the right is the average dry weight of cabbage seedlings, as well as statistical significance. The treatments of both experiments were different by Duncan test at $5 \%$ probability.

\begin{tabular}{ccccc}
\hline Suspensions & Index of plant disease & \multicolumn{1}{c}{ Dry matter (g) } \\
\hline PLP & ${ }^{(1)} 1.46$ & $\mathrm{a}$ & ${ }^{(2)} 5.1$ & $\mathrm{a}$ \\
PLPP & 1.66 & $\mathrm{ab}$ & 4.5 & $\mathrm{ab}$ \\
PLS & 1.4 & $\mathrm{a}$ & 5.1 & $\mathrm{a}$ \\
PLPS & 1.53 & $\mathrm{a}$ & 4.8 & $\mathrm{a}$ \\
Water & 2.13 & $\mathrm{~b}$ & 3.4 & $\mathrm{~b}$ \\
Control & $\mathbf{2}$ & $\mathbf{b}$ & $\mathbf{3}$ & $\mathbf{b}$ \\
\hline
\end{tabular}


bacterial cells migrated into the plant. Furthermore, we point out that the treatment with the phage suspension reduced the symptoms.

\section{Discussion}

By changing the methodology proposed by Romeiro [6], suspensions containing phages showed to be efficient biological controllers by inhibiting in vitro the growth of the pathogen in $48 \mathrm{~h}$. Often, microorganisms containing an enzymatic arsenal (bacteriocins and toxins), such as fungi and bacteria, need to screen hundreds of isolates [21]. The time period is used for screening changes when virions highly specific to their host are used in biological control [22]. While there are few studies using phages in biological control, many show the differentiated specificity of this type of virus used in serological assays [19] [20] [23].

Table 1 shows that the treatment is less efficient when using a suspension not made from the pathogen, as in many cases [24] [25]. This is because the phage specificity to their host is decreased. In the few studies where phages were used for biological control [24], they have been obtained previously by industries, which usually employ sophisticated techniques and, therefore, technical experts and expensive equipment.

Obradovic et al. [25] also made use of phages previously prepared by industries, combined with other compounds, such as SAR inducers. Balogh et al. [26] used phages in combination with copper agents to eradicate citrus canker caused by Xanthomonas citri PV. citri. However, it must be emphasized that these virions were obtained from different hosts and geographical regions and that they probably have a different genetic load from the pathogens that they are intended to control. Therefore, it was not exactly the same kind, which for compromising the method's efficacy required a synergistic use with other methods. We believe that it would be interesting to compare the method of biological control using virions with other methods; however, it is ecologically crucial to obtain a more efficient control by using only virions, since the relevance of this type of control is the null impact on the environment. It is important to note that the synergistic use of phages [7] radically changes the use of "clean" technologies directed towards the biological control's ultimate purpose.

The in vivo assay showed positive results, as only four suspensions were used: one from a lesion and the lesion-causing pathogen; one produced from this suspension, to which $2 \mathrm{~g}$ of sucrose were added; and the treatments to which inocula of the host Xanthomonas campestris PV. campestris were added to increase virion count in the medium.

As shown in Table 2, the dry weight of the treatments differed statistically from the control. The only treatment that did not differ was PLPP, while the others were able to increase the weight of the plants. The result obtained by the PLPP and PLPS suspensions can be explained mainly by filtration which the phage-containing suspensions underwent. Of course, it decreased the nutritional source for bacterial development, and since there was no host, phages were unable to increase in count in order to produce parasitism.

During the present study, we found that it is possible to improve treatment as follows: the inoculum, seeded in a medium and undergoing several filtrations, evidenced the deficit of energy in the environment. Therefore, the host (bacteria) and its parasite (phage) could not grow to a higher count. However, this can be improved by simply adding a carbohydrate source to the suspension with the host. Another way to improve the method is through bacterial ultrasonication in order to release the phage from inside of the bacteria, making them unable to parasitize the bacteria, and because, while they are inside their host, the phages are probably more virulent, thus naturally increasing the efficiency of the method. It is worth noting (Table 2 and Figure 5) that some plants did not develop over time, possibly due to the migration of some bacteria to the phloem, where they settled and formed exopolysaccharides, which inhibit the biochemical signaling by the plant, preventing the defense by the host. The study focused on Xanthomonas campestris PV. campestris; however, the method adopted may be useful in practice to control any plant bacterial disease, thus constituting an alternative to the methodology found in agronomy literature in Brazil and not requiring deep knowledge of virology. The assay showed that virions are good biological controllers capable of controlling a major pathogen (Xanthomonas campestris PV. campestris). It was shown that it is better to isolate the bacteria virion where they are etiologic agents, i.e., to isolate the bacteria from the lesion (region), then to isolate the virion and to treat the disease at the same time. Phages are very specific and to bring them from a source different from the area where the disease has settled can affect their efficiency, as suggested by the study. Based on the work conducted and from observations made throughout its course, we suggest the following methodological proposal, which will certainly be more valid than the one addressed in the present study. By ultrasonication, viruses found inside the bacteria and lost due to filtration 
of bacteria through Millipore filters will then be released. This will increase the number of virions in the medium and the suspension will contain those virions that are truly the most virulent for the pathogen, since they were able to effectively parasitize the plant pathogen. Therefore, for phage treatment, we understand that it is more efficient to follow the flow diagram shown in Figure 6. It is important to highlight that the addition of ultrasonication serves not only to the exponential growth of phage in suspension naturally improving the control, but also to a variety of other tests such as evaluating the virulence of phages inside and outside the bacteria.

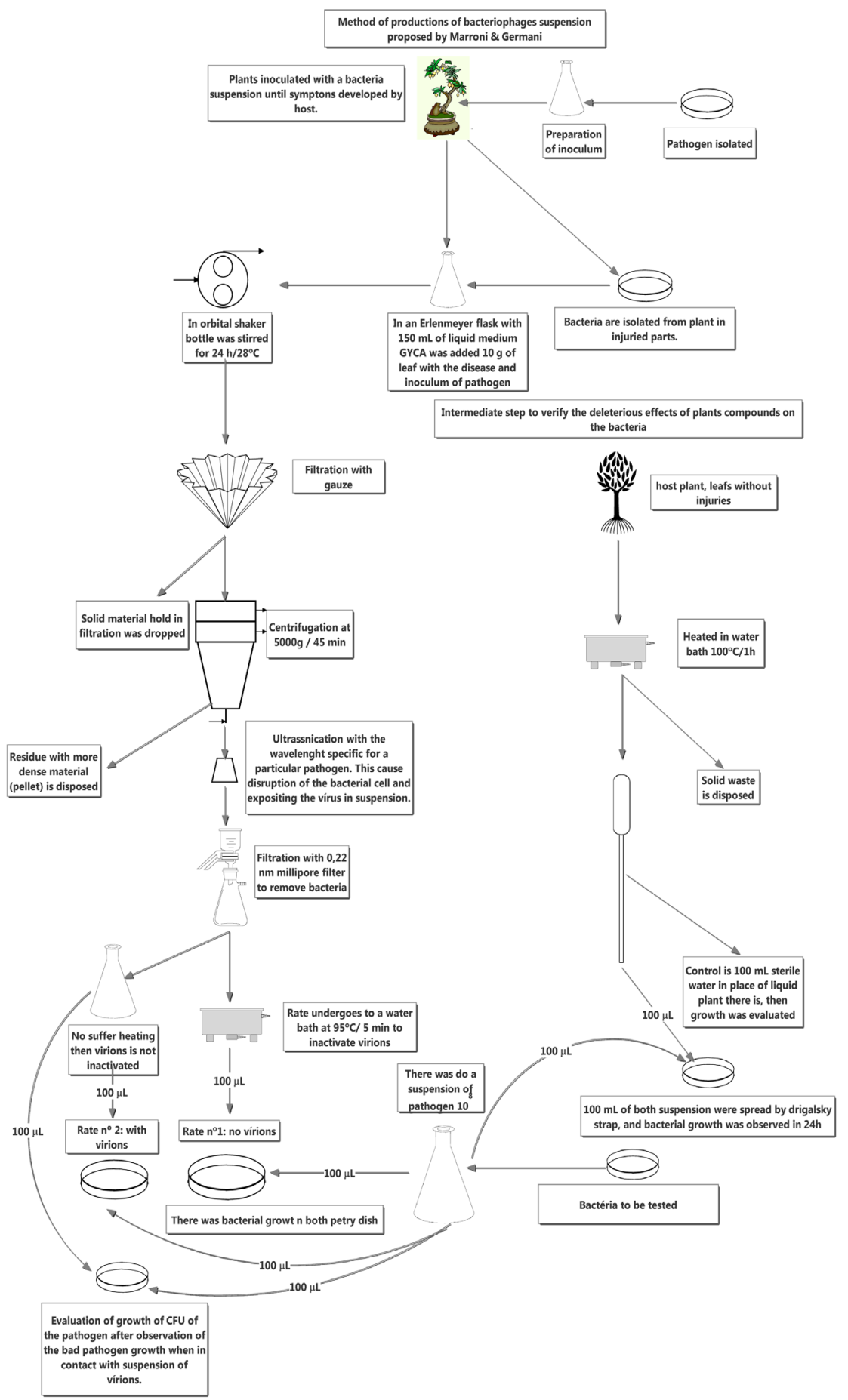

Figure 6. Improvement of methodology created by Marroni \& Germani. 
With the present study, we believe that we were able to innovate by reviewing concepts related to biological control of plant bacteria using a virus. However, the study is not conclusive, although it shows that phages are useful in controlling in vitro and in vivo important plant bacterial diseases to agriculture with no need for the synergistic use of other treatments and, above all, it employs a simple technique perfectly feasible in environment with neither technical nor developmental conditions. Therefore, further research is needed to obtain greater specificity and to improve the method of biological control.

\section{Acknowledgements}

We are grateful to the Department of Plant Sciences of the Federal University of Rio Grande do Sul for supplying leaves with Xanthomonas lesions. We also thank CAPES for their financial support.

\section{References}

[1] Mahy, B.W.J. and van Regenmortel, M.H.V. (2010) Desk Encyclopedia of Plant and Fungal Virology. Academic Press, Oxford, 613.

[2] Summers, W.C. (2005) Bacteriophage Research: Early History. In: Kutter, E. and Sulakvelidze, A., Eds., Bacteriophages: Biology and Applications, CRC Press, Boca Raton.

[3] Boyd, R.J., Hildebrandt, A.C. and Allen, O.N. (1971) Retardation of Crown Gall Enlargement after Bacteriophages Treatment. Plant Disease, 55, 145-148.

[4] Okabe, M. and Goto, M. (1963) Bacteriophages of Plant Pathogens. Annual Review of Phytopathology, 1, 397-418. http://dx.doi.org/10.1146/annurev.py.01.090163.002145

[5] Goto, M. (1992) Fundamental of Bacterial Plant Pathology. Academic Press, San Diego.

[6] Johnson, K.L., Minsavage, G.V., Le, T., Jones, J.B. and Walcott, R.R. (2011) Efficiency of a Nonpathogenic Acidovorax citrulli Strain as a Biocontrol Seed Treatment for Bacterial Fruit Blotch of Cucurbits. Plant Disease, 95, 697-704. http://dx.doi.org/10.1094/PDIS-09-10-0660

[7] Jones, J.B., Jackson, L.E., Balogh, B., Obradovic, A., Iriarte, F.B. and Momol, M.T. (2007) Bacteriophages for Plant Disease Control. Phytopathology, 45, 245-262. http://dx.doi.org/10.1146/annurev.phyto.45.062806.094411

[8] Stockwell, V.O. and Stack, J.P. (2007) Using Pseudomonas spp. for Integrated Biological Control. Phytopathology, 37, 12-18.

[9] Maketon, M., Apisitsantikul, J. and Siriraweekul, C. (2008) Greenhouse Evaluation of Bacillus subtilis AP-01 and Trichoderma harzianum AP-001 in Controlling Tobacco Diseases. Brazilian Journal of Microbiology, 39, 296-300. http://dx.doi.org/10.1590/S1517-83822008000200018

[10] Fritze, D. (2004) Taxonomy of the Genus Bacillus and Related Genera: The Aerobic Endospore Forming Bacteria. Phytopathology, 94, 1245-1248. http://dx.doi.org/10.1094/PHYTO.2004.94.11.1245

[11] Hagens, S. and Offerhaus, M.L. (2008) Bacteriophages—New Weapons for Food Safety. Food Technology, 62, 46-54.

[12] Nagy, J.K., Király, L. and Schwarczinger, I. (2012) Phage Therapy for Plant Disease Control with a Focus on Fire Blight. Central European Journal of Biology, 1, 1-12. http://dx.doi.org/10.2478/s11535-011-0093-x

[13] Matsuzaki, S., Rashel, M., Uchiyama, J., Sakurai, S., Ujihara, T., Kuroda, M., Ikeuchi, M., Tani, T., Fujieda, M., Wakiguchi, H. and Imai, S. (2005) Bacteriophage Therapy: A Revitalized Therapy against Bacterial Infectious Diseases. Japanese Society of Chemotherapy and the Japanese Association for Infectious Diseases, 11, 211-219.

[14] Shasha, S.M, Sharon, N. and Inbar, M. (2004) Bacteriophages as Antibacterial Agents. Harefuah, 143, 121.

[15] Balogh, B., Jones, J.B., Momol, M.T., Olson, S.M., Obradovic, A., King, P. and Jackson, L.E. (2003) Improved Efficacy of Newly Formulated Bacteriophages for Management of Bacterial Spot on Tomato. Plant Disease, 87, 949-954. http://dx.doi.org/10.1094/PDIS.2003.87.8.949

[16] Romeiro, R.S. (2001) Métodos em Bacteriologia de Plantas. Editora UFV, Viçosa.

[17] Svensson, U. and Christiansson, A. (1991) Methods for Phage Monitoring. Bulletin of the International Dairy Federation, 263, 29-39.

[18] Marroni, I.V., Ueno, B. and Moura, A.B. (2012) Chemical and Biological Treatments of Castor Bean Seeds: Effect on Germination, Emergence and Associated Microorganism. Revista Brasileira de Sementes, 34, 1-8. http://dx.doi.org/10.1590/S0101-31222012000100003

[19] Carzaniga, R., Fiocco, D., Bowyer, P. and O’Connell, R.J. (2002) Localization of Melanin in Conidia of Alternaria alternata Using Phage Display Antibodies. Molecular Plant-Microbe Interactions, 15, 216-224.

http://dx.doi.org/10.1094/MPMI.2002.15.3.216 
[20] Rademaker, J.L.W., Norman, D.J., Forster, R.L., Louws, F.J., Schultz, M.H. and de Bruijn, F.J. (2006) Classification and Identification of Xanthomonas translucens Isolates, Including Those Pathogenic to Ornamental Asparagus. Phytopathology, 96, 876-884. http://dx.doi.org/10.1094/PHYTO-96-0876

[21] Kohl, J., Postma, J., Nicot, P., Ruocco, M. and Blum, B. (2011) Stepwise Screening of Microorganisms for Commercial Use in Biological Control of Plant-Pathogenic Fungi and Bacteria. Biological Control, 57, 1-12. http://dx.doi.org/10.1016/j.biocontrol.2010.12.004

[22] Henriques, A.P. de A.R. (2003) Uso de Bacteriófagos para Controlo de Salmonella em Avicultura. Dissertação de Mestrado, Universidade de Aveiro, Portugal.

[23] Griep, R.A., Prins, M., van Twisk, C., Keller, H.J., Kerschbaumer, R.J., Kormelink, R., Goldbach, R.W. and Schots, A. (2000) Application of Phage Display in Selecting Tomato Spotted wilt Virus-Specific Single-Chain Antibodies (scFvs) for Sensitive Diagnosis in ELISA. Phytopathology, 90, 183-190. http://dx.doi.org/10.1094/PHYTO.2000.90.2.183

[24] Lang, J.M., Gent, D.H. and Schwartz, H.F. (2007) Management of Xanthomonas Leaf Blight of Onion with Bacteriophages and a Plant Activator. Plant Disease, 91, 871-878. http://dx.doi.org/10.1094/PDIS-91-7-0871

[25] Obradovic, A., Jones, J.B., Momol, M.T., Balogh, B. and Olson, S.M. (2004) Management of Tomato Bacterial Spot in the Field by Foliar Applications of Bacteriophages and SAR Inducers. Plant Disease, 88, 736-740. http://dx.doi.org/10.1094/PDIS.2004.88.7.736

[26] Balogh, B., Canteros, B.I., Stall, R.E. and Jones, J.B. (2008) Control of Citrus Canker and Citrus Bacterial Spot with Bacteriophages. Plant Disease, 92, 1048-1052. http://dx.doi.org/10.1094/PDIS-92-7-1048 